\title{
POLA KOMUNIKASI KONSTRUKTIF MAHASISWA SAAT MENGHADAPI TEKANAN PSIKOLOGIS DALAM PENYELESAIAN TUGAS AKHIR
}

\author{
Achmad Irfan Muzni, Awang Setiawan Wicaksono \\ Fakultas Psikologi Universitas Muhammadiyah Gresik
}

\begin{abstract}
Generally most students are feeling tense and depressed in finishing the final project. This condition if it doesn't proportionately respond it will cause severe reactions such as depression feeling that will make them can't complete their studies. This research is aiming to obtain a precise pattern of constructive communication among students in order to maintain the spirit when they faced psychological pressure while completing the final project. This study was matching methods approach which conducted at higher education institutions in Gresik. The subjects were the students who are taking the final project. Data collection did by Report Cards Card System, depth interviews and Focus Group Discussion. The data was analyzed by triangulation method. Research found in facing of psychological distress, students develop social communication patterns by opening discussion forum, telling the problem directly, asking for technical assistance, keeping and grumbling the problems and isolate their self. The constructive communication patterns that can be developed by students is providing mutual support group, sharing experiences, maintaining communication with the supervisor, discussing the issues, asking each other's progress, and pulling away to reduce the exchange of information in order to maintain concentration in finishing the final project.
\end{abstract}

Keywords: Constructive communication, psychological distress

\begin{abstract}
ABSTRAK
Umumnya sebagian besar siswa merasa tegang dan tertekan dalam menyelesaikan tugas akhir. Kondisi ini akan menyebabkan reaksi psikologis yang berat yang seperti depresi yang akan membuat mereka tidak dapat menyelesaikan studi mereka. Penelitian ini bertujuan untuk mendapatkan pola komunikasi konstruktif diantara siswa guna untuk menjaga semangat ketika mereka menghadapi tekanan psikologis saat menyelesaikan tugas akhir. Penelitian ini menggunakan matching method yang dilakukan di lembaga pendidikan tinggi di Gresik. Subjek penelitian adalah mahasiswa yang mengambil tugas akhir. Pengumpulan data dilakukan dengan menggunakan Report Cards Card System, wawancara mendalam dan Focus Group Discussion. Data dianalisis dengan metode triangulasi. Penelitian ini menemukan bahwa mahasiswa dalam menghadapi tekanan psikologis, mereka akan mengembangkan pola komunikasi sosial dengan membuka forum diskusi, mengatakan masalah secara langsung, meminta bantuan secara teknis, menyimpan sendiri, meratapi masalah dan mengisolasi diri mereka. Pola komunikasi konstruktif yang dapat dikembangkan oleh mahasiswa dengan mengadakan kelompok yang saling mendukung, berbagi pengalaman, menjaga komunikasi dengan pembimbing, membahas isu-isu, menanyakan kemajuan masing-masing dari teman yang sama-sama melakukan skripsi, dan menarik diri untuk mengurangi pertukaran informasi guna mempertahankan konsentrasi dalam menyelesaikan tugas akhir.
\end{abstract}

Kata kunci: komunikasi konstruktif, tekanan psikologis 


\section{PENDAHULUAN}

Skripsi atau tugas akhir adalah karya ilmiah yang diwajibkan sebagai bagian dari persyaratan akademik di perguran tinggi (Poerwodarminto, 1986:957). Skripsi digunakan sebagai salah satu prasyarat untuk memperoleh gelar sarjana. Pada umumnya waktu penyelesaian skripsi diberikan selama enam bulan atau satu semester, namun pada kenyataannya yang sering kali terjadi, banyak mahasiswa yang memerlukan waktu lebih dari satu semester atau enam bulan dan bahkan tidak sedikit juga mahasiswa yang pada akhirnya tidak berhasil menyelesaikan studi kesarjanaannya dikarenakan kesulitan dalam menyelesaikan tugas akhir atau skripsi.

Menurut penelitian Jung (1993)
masalah akademis menunjukkan prosentase yang paling besar dibandingkan masalah yang lainnya (Tatan, 2012). Masalah akademik yang paling kompleks yang dirasakan mahasiswa adalah saat menyusun tugas akhir atau skripsi. Mahasiswa yang sedang dalam proses menyusun tugas akhir umumnya merasa tegang dan tertekan yang jika tidak direspon secara proporsional bisa memunculkan reaksi yang lebih parah seperti depresi sehingga mahasiswa tidak bisa menyelesaikan studinya sesuai dengan target waktu yang telah ditetapkan.

Penelitian yang dilakukan oleh Catrunada (2012) menyatakan bahwa, 40 persen hambatan yang mereka rasakan saat menyusun skripsi adalah mengalami kesulitan untuk konsentrasi dengan tugas skripsi. Hal ini bisa dikarenakan adanya hal-hal lain yang memecah konsentrasi seseorang apakah karena telah bekerja, telah berkeluarga, atau karena situasi lingkungan yang tidak mendukung dalam menyelesaikan skripsi sehingga subjek tersebut melakukan penundaan. Sedangkan hambatan paling rendah yang dirasakan oleh subjek penelitian adalah adanya daya tahan tubuh yang menurun sebesar 13,33 persen. (Tatan, 2012).

Hasil penelitian di atas menunjukkan bahwa harapan mahasiswa untuk menyelesaikan tugas akhir tepat waktu terkadang tidak sama dengan realitas yang terjadi. Berbagai persoalan yang muncul mengakibatkan sebagian mahasiswa terhambat dalam menyelesaikan tugas akhirnya. Hambatan ini seringkali menjadi masalah yang dapat mengakibatkan tekanan psikologis dalam bentuk stres.

Stres adalah suatu kondisi yang muncul manakala individu menilai bahwa situasi yang dihadapinya mengancam dan dirinya tidak memiliki kemampuan untuk mengatasi permasalahan tersebut (Lazarus \& Folkman, 1984). Stres dapat diatasi dengan melakukan strategi coping yang efektif. Salah satu hal yang mempengaruhi individu dalam melakukan strategi coping adalah dukungan sosial (Lazarus \& Folkman, 1984). Hasil penelitian Cobb (Vaux, 1988) membuktikan adanya dukungan sosial yang adekuat dari orang terdekat dapat melindungi individu dari hambatan atau gangguan fisiologis dan psikologis, serta mampu memfasilitasi individu untuk melakukan adaptasi.

Dukungan sosial merupakan sesuatu yang diberikan oleh keluarga, teman dekat, pembimbing atau rekan kerja, yang berkaitan dengan peristiwa sehari-hari, seperti berbagi perasaan dan pekerjaan, 
bertukar informasi dan afeksi, mempertahankan semangat dalam kebahagiaan dalam cinta, kepedihan, ikatan keluarga, serta ikatan pertemanan (Vaux, 1988).

Dalam konteks perkuliahan, mahasiswa dalam menjalani perkuliahan tidak dapat dipisahkan dari adanya teman sebaya. Teman sebaya bertindak sebagai orang kepercayaan yang penting dan menolong individu dalam melewati berbagai situasi yang menjengkelkan dengan menyediakan dukungan emosi dan nasihat yang memberikan informasi (Savin-Williams \& Berndt dalam Santrock, 2003). Oleh karena ketika mahasiswa mulai menghadapi tugas akhir, melalui komunikasinya dengan teman sebaya mereka mampu memperoleh segala informasi terkait proses teknis bahkan pembentukan persepsi akan tekanan psikologis yang akan dihadapi dalam mengerjakan tugas akhir dari lingkungan.

Dukungan sosial teman dapat membantu mahasiswa untuk menghadapi segala persoalan yang dihadapi karena dukungan sosial teman dapat membantu mereka mendapatkan informasi mengenai langkah-langkah yang penelitian harus ditempuh dan saling memberikan masukan dengan temannya ketika merasa buntu atau kekurangan ide. Selain itu, mereka juga saling mendukung dan mengingatkan ketika ada di antara mereka yang mulai menunda penyelesaian tugasnya. Oleh karena itulah dalam menghadapi tekanan psikologis ketika menyelesaikan tugas akhir mahasiswa sangat membutuhkan adanya iklim sosial yang tepat yang didukung dengan adanya pola komunikasi yang konstruktif untuk menghadapi tekanan psikologis ketika menyelesaikan tugas akhir.

\section{Tujuan Penelitian}

Tujuan dari penelitian ini adalah:

1. Mengetahui bentuk permasalahan yang dihadapi mahasiswa ketika menyelesaikan tugas akhir

2. Mengetahui bentuk dukungan yang dibutuhkan mahasiswa untuk dapat bertahan menghadapi tekanan psikologis ktika menyelesaikan tugas akhir

3. Memperoleh gambaran pola komunikasi sosial yang dilakukan oleh mahasiswa ketika menghadapi tugas akhir

4. Memperoleh gambaran pola komunikasi konstruktif yang paling tepat bagi mahasiswa dalam mempertahankan semangat ketika menghadapi tekanan psikologis saat menghadapi tugas akhir

\section{Tugas Akhir/Skripsi}

Wirartha (2006) mengatakan bahwa skripsi adalah karya tulis ilmiah seorang mahasiswa dalam menyelesaikan program S1. Skripsi tersebut adalah bukti kemampuan akademik mahasiswa bersangkutan dalam penelitian dengan topik yang sesuai dengan bidang studinya. Skripsi disusun dan dipertahankan untuk mencapai gelar sarjana strata satu. Biasanya, skripsi menjadi salah satu syarat kelulusan (Tatan, 2012: 92). Sementara itu, menurut buku panduan penulisan skripsi/tugas akhir Unindra dikatakan: "Skripsi adalah suatu karya ilmiah yang disusun oleh seorang mahasiswa berdasarkan hasil penelitian dengan menggunakan data primer atau data sekunder yang penulisannya terikat pada sistematika formal dan tunduk pada asas logika ilmiah serta metodologi yang benar" (Tatan, 2012 : 92). 
Berdasarkan teori-teori di atas, yang dimaksud skripsi dalam penelitian ini adalah suatu karya ilmiah yang disusun oleh seorang mahasiswa berdasarkan hasil penelitian dengan menggunakan data primer atau data sekunder yang penulisannya terikat pada sistematika formal dan tunduk pada asas logika ilmiah serta metodologi yang benar.

\section{Tekanan Psikologis/Stres}

Stres adalah suatu keadaan psikologis individu yang disebabkan karena individu dihadapkan pada situasi internal maupun eksternal. Stres muncul apabila terdapat tuntutan-tuntutan yang luar biasa atau terlalu banyak ancaman dalam kesejahteraan atau integritas seseorang. Stres tidak hanya muncul pada kondisi yang menekan ataupun keadaan fisik atau psikologis seseorang maupun reaksi terhadap tekanan, akan tetapi stres terkait di dalam ketiganya.

Menurut Patel (dalam Maifrisco: 2008) Stres merupakan reaksi tertentu yang muncul pada tubuh yang bisa disebabkan oleh berbagai tuntutan, misalnya ketika manusia menghadapi tantangan-tantangan (challenge) yang penting, ketika dihadapkan pada ancaman (threat), atau ketika harus berusaha mengatasi harapan-harapan yang tidak realistis dari lingkungannya.

Stres merupakan keadaan atau situasi yang menuntut seseorang di luar batas kemampuannya untuk beradaptasi. Charles D. Spielberger menyatakan bahwa stres adalah tuntutan-tuntutan eksternal yang mengenai seseorang, misalnya objek-objek dalam lingkungan atau suatu stimulus yang secara objektif adalah berbahaya. Tuntutan itu dapat bersifat fisik, psikologis, sosial, atau beberapa kombinasi dari faktor-faktor tersebut.
Stres juga dapat diartikan sebagai tekanan, ketegangan atau gangguan yang tidak menyenangkan yang berasal dari luar diri seseorang. Stimuli objektif dari lingkungannya dievaluasi berdasarkan latar belakang sosiokultural, pengalaman pribadi dan faktor-faktor individual lainnya.

\section{Proses Timbulnya Tekanan Psikologis/Stres}

Tekanan psikologis/ stress menurut Hawari (2001) dapat dibagi dalam tiga tahap reaksi terhadap stres, yaitu :

1. Tahap Sinyal; Mobilasi awal dimana badan menemui tantangan yang diberikan oleh penyebab stres. Ketika penyebab stres ditemukan, otak mengirimkan suatu pesan biokomia kepada semua system tubuh. Pernafasan meningkat, tekanan darah naik, anak mata membesar, ketegangan otot naik, dan seterusnya. Jika stress terlalu kuat, terjadi luka pada saluran pencernaan, kelenjar adrenalin membesar dan thymus menjadi lemah. Kalau penyebab stres terus aktif maka beralih ke tahap perlawanan. Contoh: seorang siswa yang diminta oleh gurunya menyelesaikan 60 soal fisika dalam waktu kurang dari satu jam.

2. Tahap Perlawanan; Ditandai dengan keletihan, ketakutan dan ketegangan. Individu yang mengalami tahap ini akan melawan penyebab stres. Keterbatasan konsentrasi, sumber energi yang dimiliki dan untuk menahan penyebab-penyebab stres, individu sering lebih sakit selama periode ini daripada pada tahap lain. Contoh: menjadi marah pada saat waktu habis karena tugas belum selesai.

3. Tahap Kelelahan; Individu diharapkan pada penyebab stres yang sama dalam 
jangka panjang dan terus-menerus sehingga pada akhirnya menaikkan penggunaan energi penyesuaian yang biasa dan system penyerang penyebab stres menjadi lelah. Contoh: pelajar tidak tidur, khawatir tugasnya belum selesai.

Sedangkan menurut Braham, gejala stres dapat berupa tanda-tanda berikut ini :

1. Fisik, yaitu sulit tidur atau tidur tidak teratur, sakit kepala, sulit buang air besar, adanya gangguan pencernaan, radang usus, kulit gatal-gatal, punggung terasa sakit, urat-urat pada bahu dan leher terasa tegang, keringat berlebihan, berubah selera makan, tekanan darah tinggi atau serangan jantung, kehilangan energi.

2. Emosional, yaitu marah-marah, mudah tersinggung dan terlalu sensitif, gelisah dan cemas, suasana hati mudah berubah-ubah, sedih, mudah menangis dan depresi, gugup, agresif terhadap orang lain dan mudah bermusuhan serta gampang menyerang, dan kelesuan mental.

3. Intelektual, yaitu mudah lupa, kacau pikirannya, daya ingat menurun, sulit untuk berkonsentrasi, suka melamun berlebihan, pikiran hanya dipenuhi satu pikiran saja.

4. Interpersonal, yaitu acuh dan mendiamkan orang lain, kepercayaan pada orang lain menurun, mudah mengingkari janji pada orang lain, senang mencari kesalahan orang lain atau menyerang dengan kata-kata, menutup diri secara berlebihan, dan mudah menyalahkan orang lain.

\section{Komunikasi}

Komunikasi didefinisikan oleh Dance (1970) sebagai suatu proses dimana seorang komunikator menyampaikan stimulus (biasanya bersifat verbal) dengan tujuan untuk melakukan perubahan perilaku orang lain. Sedangkan Ross (1974) mendefinisikan komunikasi sebagai suatu proses transaksional yang meliputi pemilihan dan pemetaan secara kognisi, dan berbagi simbol yang bertujuan untuk membantu orang lain untuk memperoleh makna dari pengalaman yang dialami atau suatu respon yang mirip dengan sumber stimulus. (Rakhmat, 2004: 3).

Komunikasi memiliki makna yang luas, meliputi segala penyampaian energi, gelombang suara, tanda diantara tempat, sistem atau organisme. Menurut Tubbs dan Moss (1974) dalam Rakhmat Komunikasi yang efektif paling tidak menimbulkan lima hal: pengertian, kesenangan, pengaruh pada sikap, hubungan yang makin baik, dan tindakan. (Rakhmat, 2004:13).

\section{Jenis-Jenis Komunikasi}

Menurut Hartley (1993) terdapat beberapa jenis komunikasi yaitu antar individu dan antara individu dan massa. Diantara kedua jenis komunikasi tersebut komunikasi antar individu yang langsung adalah proses komunikasi yang paling lengkap mengandung berbagai faktor psikologis. Komunikasi antar individu menurut Hartley (1993), mengandung beberapa aspek, pertama tatap muka, dalam tatap muka ada beberapa peran yang harus dijalankan an diprlukan adanya saling kepercayaan. Kedua dalam komunikasi antar individu terdapat komunikasi dua arah yang didalamnya terjadi pertukaran pesan secara aktif antara penyampai informasi dengan penerima informasi. Ketiga adalah adanya niat atau kehendak dari kedua belah pihak. Ketiga proses ini sangat terkait dengan waktu durasi berlangsungnya komunikasi. (Sarwono, 2002: 193-196). 
Dalam proses komunikasi perasaan atau emosi juga dapat berpengaruh pada interaksi yang terjadi. Menurut Downey \& Damhave (1991), apabila kita berinteraksi dengan seseorang dan reaksi yang diberikannya bermusuhan maka efek yang ditimbulkan pada diri kita adalah kemarahan. Sedangkan jika reaksi awalnya adalah menghargai dan menyenangkan maka emosi yang ditimbulkan adalah emosi positif (Sarwono, 2002:199). Dengan demikian terlihat jika emosi individu sangat dipengaruhi oleh stimulasi lingkungan yang ada disekitarnya ketika ia menjalin interaksi dengan lingkungan sekitarnya.

\section{Aspek - Aspek Dalam Komunikasi}

Menurut Baroody (1993) ada lima aspek komunikasi. Kelima aspek itu adalah:

1. Representasi;

Representasi

(representating) adalah: (a) bentuk baru sebagai hasil translasi dari suatu masalah, atau ide, (b) translasi suatu Sebaran atau model fisik ke dalam simbol atau kata-kata.

2. Mendengar; Mendengar secara hatihati terhadap pertanyaan teman dalam suatu grup juga dapat membantu siswa mengkontruksi lebih lengkap pengetahuan.

3. Membaca (reading) adalah aktivitas membaca teks secara aktif untuk mencari jawaban atas pertanyaanpertanyaan yang telah disusun. Pembaca yang baik terlibat aktif dengan teks bacaan dengan cara: (a) membangun pengetahuan dalam pikiran mereka berdasarkan apa yang telah mereka ketahui, (b) menggunakan strategi untuk memahami teks bacaan dan mengorganisasikannya dalam bentuk visual berupa bagan, Sebaran, atau outline (c) memonitor, merencanakan dan mengatur pembentukan makna, (d) membangun penafsiran atau pemahaman teks bacaan yang bermakna dalam memori jangka pendek, dan (e) menggunakan strategi dan pengetahuan yang sudah ada yang digali dalam memori jangka panjang.

4. Diskusi (discussing) merupakan sarana untuk mengungkapkan dan merefleksikan pikiran.

5. Menulis (writing) adalah suatu kegiatan yang dilakukan dengan sadar untuk mengungkapkan dan merefleksikan pikiran.

\section{Komunikasi Konstruktif}

Menurut Fine (2008), Komunikasi yang konstruktif dapat terbentuk apabila proses komunikasi yang dilakukan memenuhi beberapa syarat sebagai berikut:

1. Berorientasi pada masalah; yaitu berfokus pada masalah yang bisa diselesaikan dan memfokuskan diri pada menghindari atau menyelesaikan masalah dimasa mendatang.

2. Pembicaraan kongruen; yaitu menyampaikan apa yang pembicara pikirkan dan rasakan. Proses komunikasi secara lebih efektif dengan bersikap jujur secara konstruktif sehingga membuat pendengar mempercayai apa yang dikatakan.

3. Pembicaraan deskriptif; yaitu dengan mengekspresikan deskripsi obyektif masalah, bukan evaluasi terhadap masalah.

4. Memberikan Validasi; yaitu dengan membantu orang merasa dimengerti, dihargai, dan diterima. Komunikasi yang memvalidasi berfokus pada pencarian titik temu. 


\section{METODE PENELITIAN}

Jenis penelitian ini adalah penelitian diskriptif yang menggabungkan antara penelitian kuantitatif dan kualitatif atau apa yang disebut oleh Julia Brannen (1997) disebut dengan pendekatan matching methode. Penelitian ini menggunakan metode survei, observasi dan wawancara.

Lokasi penelitian dilakukan di lima perguruan tinggi yang berada di wilayah Kabupaten Gresik Jawa Timur dengan Subyek penelitian adalah mahasiswa yang sedang mengambil mata kuliah tugas akhir atau skripsi pada kelima perguruan tinggi tersebut.

Pengambilan data dilakukan dengan cara Metode Raport Card System (RCS), Indepth Interview dan Focus Group Discusion (FGD).

Analisa data menggunakan metode ganda (triangulasi method) yang bisa terjadi antar metode atau bisa di dalam metode. Secara kuantitatif menggunakan metode Raport Card System (RCS). Setelah dilakukan analisa kuantitatif kemudian digabungkan dengan analisa kualitatif dengan metode triangulasi sehinggan menurut Miles dan Huberman (1992) mempertegas bahwa dalam konteks analisa data pada tahapan yang dilakukan dimulai dari pengumpulan data, reduksi data, penyajian data, dan kesimpulan-kesimpulan dari data yang terdiri kemudian penarikan kesimpulan dan verifikasi data.

\section{HASIL DAN PEMBAHASAN}

\section{Profil Mahasiswa Yang Menyelesaikan Skripsi/Tugas Akhir}

Berdasarkan data yang diperoleh dari data penyebaran kuesioner dalam bentuk sistem laporan (report card system) yang menggunakan format pertanyaan terbuka, dari identitas pengisi kuesioner dapat digambarkan jika mayoritas jenis kelamin responden adalah perempuan sejumlah 56 persen dan laki-laki sejumlah 44 persen (gambar. 1).

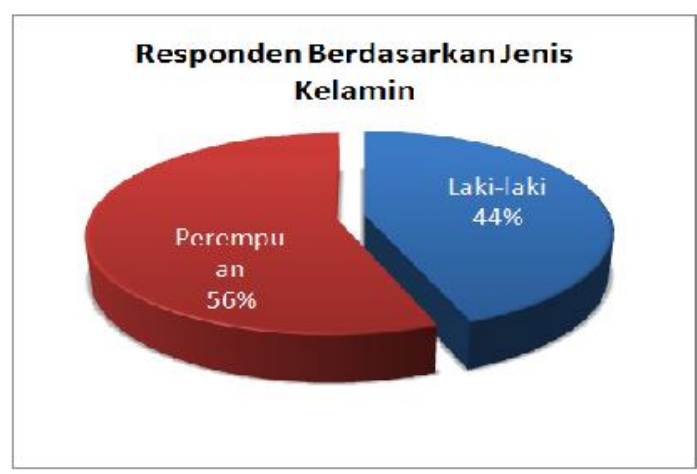

Gambar 1. Sebaran Karakteristik Responden Berdasarkan Jenis Kelamin

Dari kuesioner sebagaimana terlihat pada gambar 2, juga dapat terlihat jika mayoritas responden yang terlibat dalam penelitian ini membutuhkan waktu 2 bulan hingga 30 bulan untuk menyelesaikan skripsi/tugas akhirnya, dengan rincian mayoritas responden membutuhkan waktu 6 bulan sejumlah 24 persen, 12 bulan sejumlah 22 persen, 3 bulan sejumlah 20 persen, 5 dan 8 bulan masing masing sejumlah 6 persen, 24 bulan sejumlah 4 persen dan 2 bulan dan 30 bulan sejumlah masing-masing 2 persen. Dari data tersebut terlihat jika mayoritas waktu normal yang dibutuhkan untuk menyelesaikan skripsi/tugas akhir berkisar antara 3 hingga 12 bulan atau antara satu hingga dua semester. 


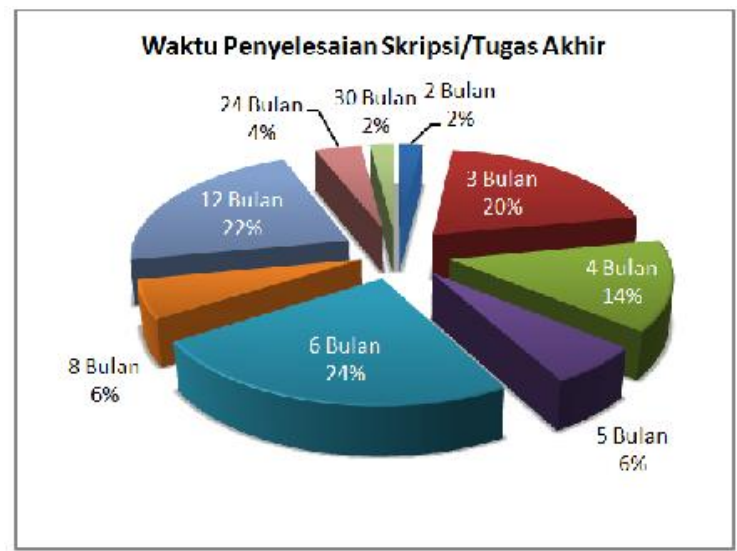

Gambar 2. Sebaran Rentang Waktu Penyelesaian Skripsi/Tugas Akhir Mahasiswa

\section{Perasaan Ketika Menyelesaikan Skripsi/Tugas Akhir}

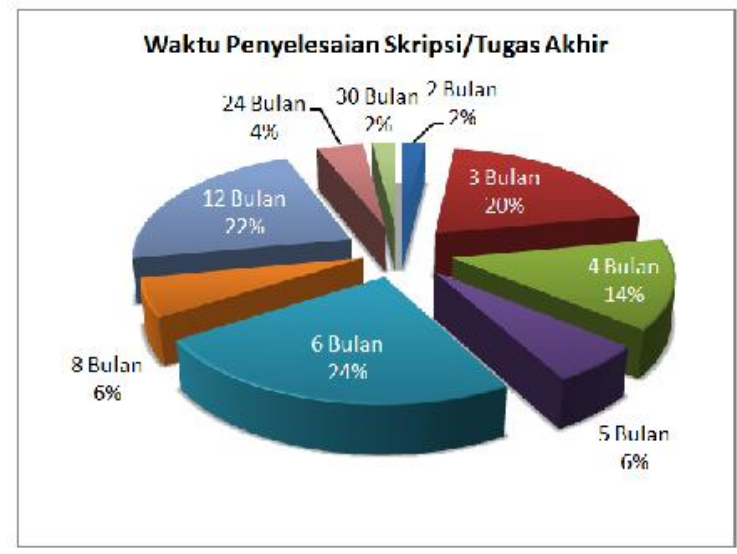

Gambar 3. Sebaran Gambaran Perasaan Mahasiswa Ketika Menyelesaikan Skripsi/Tugas Akhir

Pada gambar 3 diatas juga dapat terlihat jika mayoitas mahasiswa 32 persen yang menyelesaikan skripsi mengalami kebingungan dan rasa pusing yang tidak diketahui sebabnya. Selain itu sejumlah 18 persen mahasiswa juga merasa cemas dan takut terhadap proses penyelesaian skripsi yang akan dijalani. Sedangkan sisanya sejumlah 22 persen mahasiswa merasa senang karena mereka yang merasa telah mencapai masa akhir dari masa studi yang panjang yang telah ditempuh. Berdasarkan keterangan pendalaman yang diperoleh dari hasil focus group discussion (FGD), mayoritas mahasiswa yang telah merasakan adanya kecemasan diawal proses skripsi/tugas akhirnya akan mengalami tekanan berlebihan yang makin membuatnya merasa cemas dan semakin takut untuk menjalani rangkaian proses penelitian yang akan dilakukan dan hal ini akan membuatnya menjauhkan diri dari lingkungan kampus.

\section{Permasalahan Yang Dihadapi Ketika Menyelesaikan Skripsi/Tugas Akhir}

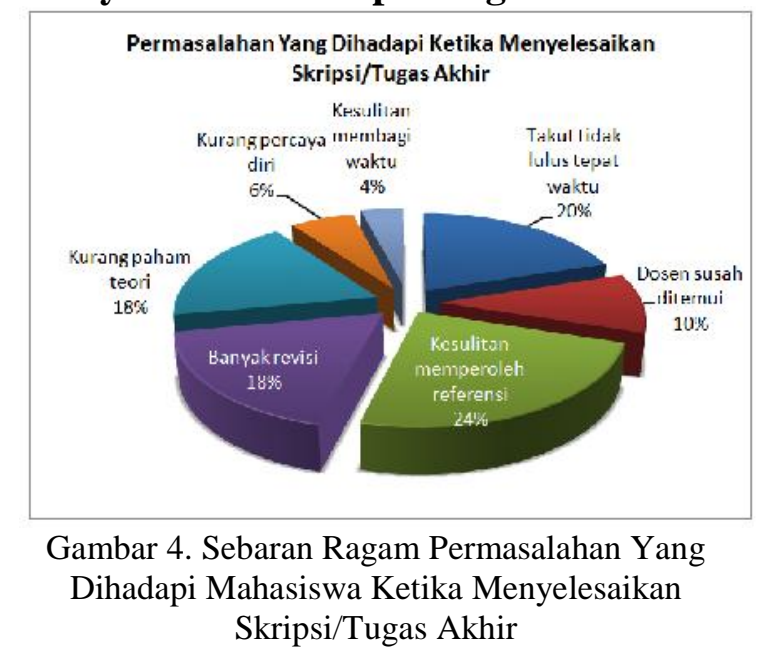

Meski pada umumnya ketika menghadapi proses penyelesaian skripsi mahasiswa yang bersangkutan telah menyelesaikan masa perkuliahannya dikelas namun bukan berarti hal ini membuat mereka terhindar dari berbagai persoalan akademis sehingga memiliki keleluasaan waktu untuk menyelesaikan skripsi/tugas akhirnya. Pada kenyataanya justru pada kondisi ini mayoritas mahasiswa akan menemui kendala yang tidak terlalu dirasakannya ketika menjalani perkuliahan. Berdasarkan data yang diperoleh dari kuesioner yang ditampilkan pada gambar 4 diatas dapat diketahui jika sejumlah 24 persen mahasiswa akan mengalami kesulitan dalam mengakses referensi yang dibutuhkannya dalam menyelesaikan skripsi/tugas akhirnya. Dan 20 persen 
diantaranya akan rentan dilanda ketakutan jika tidak dapat lulus tepat waktu sedangkan 18 persen yang lain merasa cukup terbebani dengan tekanan revisi yang banyak dan hal ini diperparah dengan adanya ketidakpahaman akan dasar teori yang dijadikan landasan dalam melakukan penelitian.

Selain itu adanya kesibukan dosen juga turut memberikan kontribusi pada masalah yang dihadapi mahasiswa, sejumlah 10 persen responden merasa jika mereka merasa kesulitan untuk dapat sekedar menemui dan berkomunikasi dengan dosen pembimbingnya. Meski permasalahan ini cukup banyak disebabkan dinamika eksternal, namun terlihat jika masih ada sebagian kecil mahasiswa yang memiliki masalah yang disebabkan dinamika internal dirinya diantaranya karena kurangnya rasa percaya diri (6\%) dan kesulitan mahasiswa dalam membagi waktu (4\%).

\section{Tindakan Yang Dilakukan Dalam} Menghadapi Permasalahan

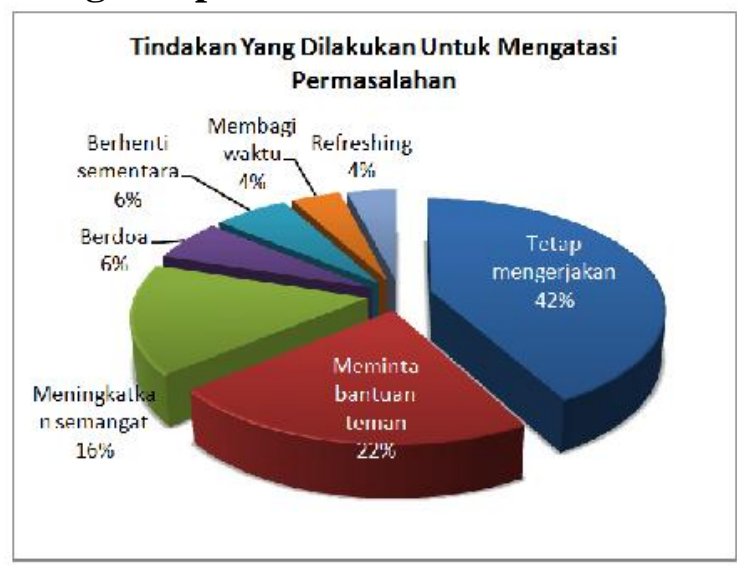

Gambar 5. Sebaran Ragam Tindakan Yang Dilakukan Untuk Menghadapi Permasalahan Ketika Menyelesaikan Skripsi/Tugas Akhir

Ditinjau dari pilihan tindakan yang dipilih mahasiswa dalam mengatasi permasalahan yang dihadapi ketika menyelesaikan skripsi/tugas akhir diatas (dalam gambar 4) maka mayoritas responden (42\%) memilih untuk tetap mengerjakan skripsi/tugas akhirnya seiring mereka melakukan rekonstruksi kondisi psikologis dirinya, sedangkan sebagian $(22 \%)$ memilih untuk meminta bantuan dari teman disekitarnya yang dianggap mampu untuk memberikan bantuan padanya dalam menghadapi permasalahan.

Meski ada sebagian mahasiswa (16\%) yang berusaha untuk meningkatkan semangat dengan berbagai cara, ada juga sebagian mahasiswa (6\%) yang memilih untuk berdoa dan lebih memilih untuk sementara waktu berhenti mengerjakan skripsi/tugas akhir. Dan sisanya (4\%) memilih untuk menata kembali prioritas aktifitasnya serta memilih untuk mencari suasana baru dengan harapan agar dapat lebih efektif dalam menata diri untuk lebih memfokuskan perhatiann dan konsentrasinya pada proses penyelesaian skripsi/tugas akhirnya.

\section{Sosok Yang Sering Dimintai Dukungan Psikologis Ketika Menghadapi Permasalahan Dalam Menyelesaikan Skripsi/Tugas Akhir}

Sebagaimana yang tergambar pada gambar 6 dibawah ini, dapat diketahui jika ketika mahasiswa yang sedang menghadapi proses penyelesaian skripsi/tugas akhir akan merasakan tekanan yang berlebihan pada dirinya, maka ia akan membutuhkan hadirnya sosok disekitarnya untuk memberikan dukungan moral padanya. Mayoritas responden menyatakan jika mereka akan berusaha untuk mendapatkan dukungan dari teman yang sama-sama menyelesaikan skripsi/tugas akhir (36\%) dan yang lain akan mencurahkan perasaan kecemasann dan ketertekanannya pada sahabat dekat maupun keluarganya (18\%). 


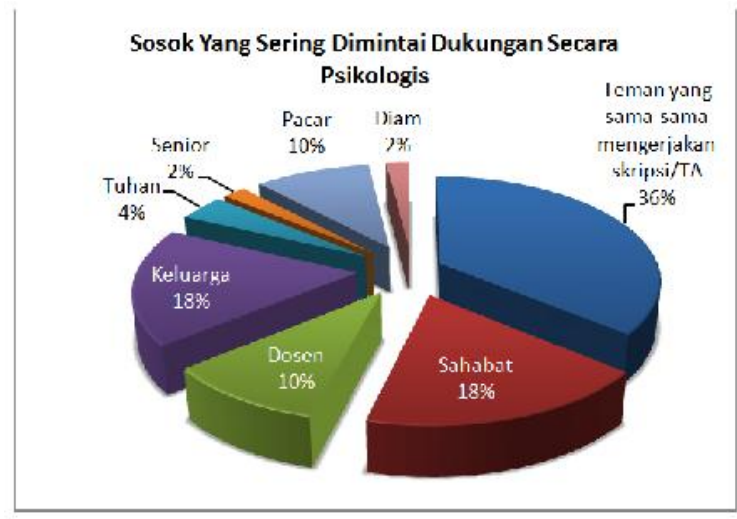

Gambar 6. Sosok Yang Dimintai Dukungan Secara Psikologis Ketika Menyelesaikan Skripsi/Tugas Akhir

Sedangkan $10 \%$ responden yang lain lebih memilih untuk mengungkapkan apa yang dirasakannya pada dosen pembimbingnya dengan harapan agar permasalahan yang dihadapi dapat segera mendapatkan solusi dari dosen yang membimbingnya yang dianggapnya mengerti tentang permasalahan yang dihadapinya. Hal ini rata-rata dilakukan oleh para mahasiswa yang memiliki persepsi positif atas pembimbingnya, dengan kata lain mereka akan melakukan hal tersebut jika mereka merasa dosen pembimbingnya memiliki tingkat kepedulian yang tinggi pada permasalahan yang dialami oleh mahasiswa bimbingannya. Selain itu, mahasiswa yang lain akan memilih untuk menyampaikan persoalannya pada pacarnya yang dianggapnya cukup dekat dan mengenal dirinya.

\section{Tanggapan Lingkungan Terhadap Persoalan Yang Dihadapi}

Meski kendala dalam mengerjakan skripsi pernah dirasakan oleh seluruh pribadi yang pernah mengenyam pendidikan setingkat sarjana ( $\mathrm{S}-1)$ namun ternyata tidak semua pribadi memiliki respon yang sama dalam memberikan perhatian pada permasalahan yang dialami oleh mahasiswa yang sedang menyelesaikan skripsi/tugas akhirnya. Hal ini tampak pada data yang ditampilkan pada gambar 7 dibawah ini dimana ternyata masih terdapat beberapa responden yang merasa kurang dipedulikan oleh lingkungannya. Masih terlihat ada 4 persen responden yang merasa kurang dipedulikan oleh lingkungannya.

Meski demikian juga terlihat jika masih banyak juga responden yang merasakan mendapat dukungan dari lingkungan hal ini terbukti dari adanya 46 persen responden merasa jika dirinya senantiasa mendapat dukungan motivasi dari lingkungan sekitarnya, 14 persen responden merasa mendapat simpati rasa prihatin dari lingkungan dan bahkan 12 persen responden yang lain merasa mendapatkan tawaran bantuan yang nyata dalam menyelesaikan skripsi/tugas akhirnya dalam bentuk peminjaman literatur yang dibutuhkan, bantuan menyebarkan dan mengolah data. Sedangkan sisanya yang lain mendapatkan masukan saran (10\%) dan tawaran solusi atas permasalahan yang dihadapi (8\%) dalam bentuk usulan judul untuk ditindaklanjuti.

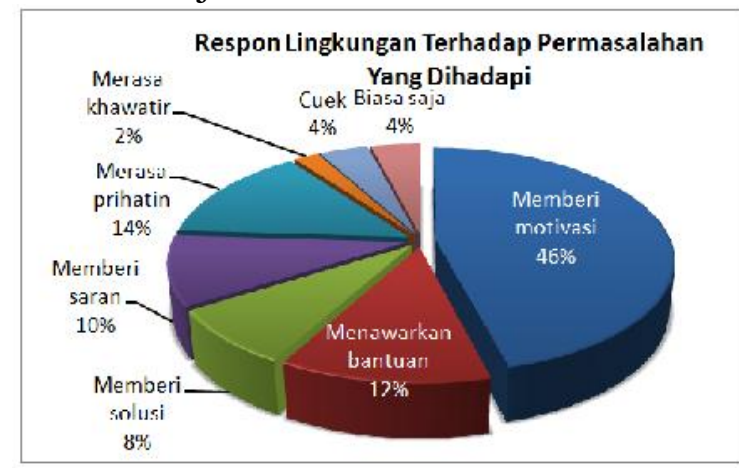

Gambar 7. Sebaran Ragam Respon Lingkungan Terhadap Permasalahan Yang Dihadapi Mahasiswa Ketika Menyelesaikan Skripsi/Tugas Akhir 


\section{Kesesuaian dan Bentuk Respon Lingkungan Yang Diharapkan Oleh Mahasiswa Yang Sedang Menyelesaikan Skripsi/Tugas Akhir}

Pada data yang ditunjukkan oleh gambar 8 menampilkan jika mayoritas responden $(68 \%)$ merasakan jika respon yang diberikan responden padanya telah sesuai dengan harapan yang dimiliki, dan hanya sebagian kecil (12\%) merasakan jika respon lingkungan yang diterimanya tidak sesuai dengan harapannya. Kesesuaian respon lingkungan ini secara lebih detail ditampilkan oleh rangakaian data yang tergambar pada gambar 9 dibawah ini. Dimana pada gambar 9 terlihat jika 39 persen responden merasa mendapat dukungan semangat yang memadai dari lingkungan sekitarnya. Meski sebagian responden berharap adanya respon yang tidak sekedar berbentuk dorongan semangat dan lebih menghendaki adanya bantuan langsung yang bersifat teknis (27\%), namun harapan ini masih dapat ditekan dengan kesadaran yang matang dari masingmasing responden akan kesibukan lingkungannya.

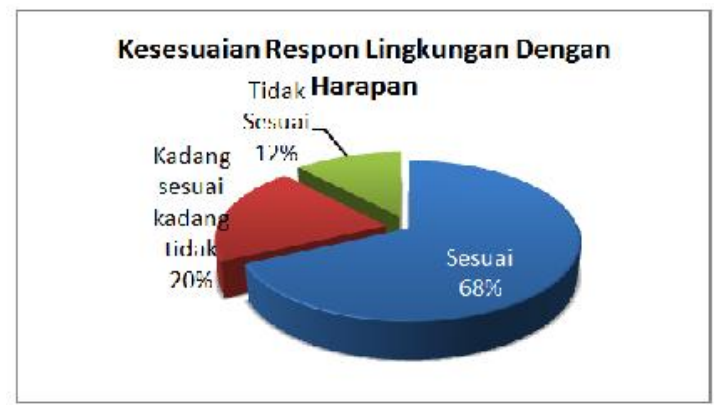

Gambar 8. Sebaran Kesesuaian Respon Lingkungan Dengan Harapan Mahasiswa

Dari gambar 9 juga terlihat jika masih cukup banyak responden (10\%) yang cukup mengapresiasi ketika mendapat respon yang positif akan kondisi yang sedang dialaminya dari lingkungan sekitarnya. Selain itu sebagian responden yang lain (8\%) merasa cukup dengan mendapatkan masukan ide dan solusi atas permasalahan yang dihadapi, meski belum tentu solusi yang ditawarkan akan dapat diterapkan pada penyelesaian masalah yang dihadapi. Bagi sebagian kelompok responden yang lain $(6 \%)$ berserah diri dan kembali mendekatkan diri pada Tuahn adalah pilihan langkah yang tepat atau justru tidak terlalu mempedulikan respon lingkungan akan menjadi pilihan sikap yang tepat untuk mengurangi rasa kecewa terhadap sekitarnya. Sedangkan sebagian kecil responden (4\%), hanya memperoleh kesempatan untuk didengarkan/disediakan waktu untuk didengarkan permasalahan yang dihadapi dapat membuatnya merasa cukup untuk kembali bersemangat menghadapi tekanan skripsi/tugas akhir.

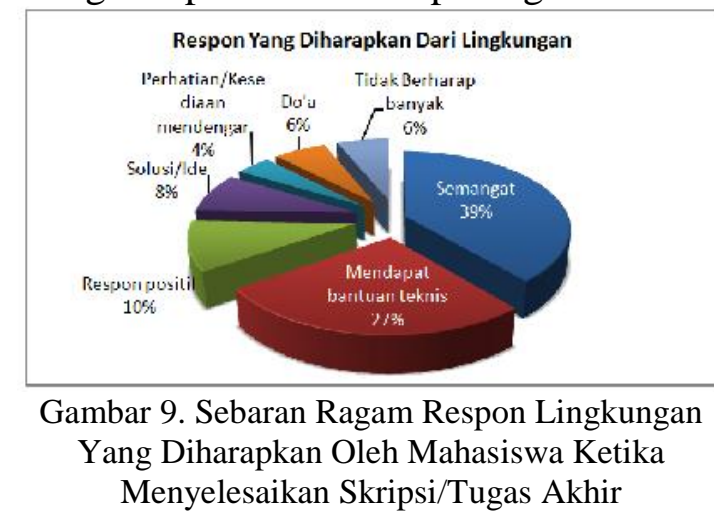

Cara Mahasiswa Menyampaikan Permasalahan Yang Dihadapi Terkait Penyelesaian Skripsi/Tugas Akhirnya Pada Orang Lain

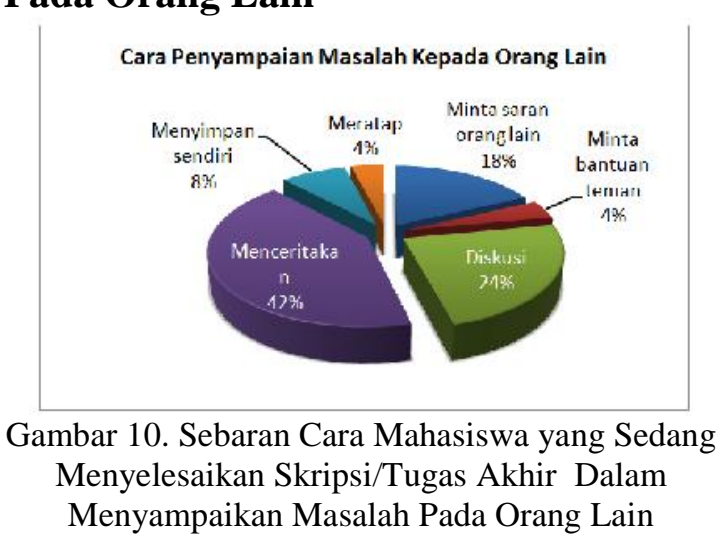


Pada gambar 10 dapat terlihat jika langkah yang dibuat oleh para responden dalam mengkomunikasikan permasalahan yang sedang dihadapinya pada orang lain adalah dengan menceritakannya melalui forum tidak resmi yang terbentuk secara insidental untuk mereka sharing pengalaman dan permasalahan diantara sesamanya, sejumlah 42 persen responden memilih cara ini sebagi cara mereka untuk menyalurkan permasalahan yang dihadapi, sedangkan sekelompok yang lain lebih memilih forum diskusi tematik (24\%) untuk mengurangi kebingungan mereka dalam memahami konsep maupun persoalan yang akan mereka jadikan topik penelitian akhir mereka.

Pada kelompok yang lain mengkomunikasikan permasalahan dengan mengungkapkan kebutuhan pada orang lain dengan harapan untuk mendapatkan saran dan masukan yang lebih tepat dari orang yang dipandangnya lebih menguasai materi akan menjadi solusi yang tepat untuk menyalurkan kebimbangannya, sejumlah 18 persen responden memilih cara ini sedangkan 12 persen sisanya lebih memilih untuk menyimpan permasalahannya dari orang lain (8\%) dan meratapi nasib yang dialaminya dengan menyendiri dan mengasingkan diri dari lingkungannya $(4 \%)$. Pada umumnya pada individu yang memilih dua pilihan langkah terakhir ini akan cenderung mengalami kesulitan untuk kembali membangkitkan semangat dan kembali menyelesaikan skripsi/tugas akhirnya dan tidak jarang sebagian dari mereka akan mengalami putus ditengah jalan dan tidak berhasil menyelesaikan studinya.

\section{Frekwensi Komunikasi Mahasiswa Dengan Lingkungan Sekitarnya Ketika Menyelesaikan Skripsi/Tugas Akhir}

Mayoritas mahasiswa yang sedang menyelesaikan skripsi/tugas akhir akan membutuhkan lingkungan yang tepat dan ia butuh untuk dekat dengan lingkungan ini untuk memberikan dorongan baginya dalam mempertahankan semangatnya agar dapat menyelesaikan penelitiannya tepat pada waktunya. Oleh karena itulah mereka akan membutuhkan komunikasi yang intens dengan kelompoknya. Hal ini seperti yang terlihat pada gambar 11 dibawah ini, dimana lebih dari 76 persen responden akan melakukan komunikasi setiap hari dengan rekan lain yang sedang sama-sama menyelesaikan skripsi/tugas akhir. Sedangkan yang lain (14\%) memilih untuk hanya akan menjalin komunikasi ketika ia merasa sedang menghadapi masalah dan membutuhkan bantuan dari orang lain untuk menyelesaikannya.

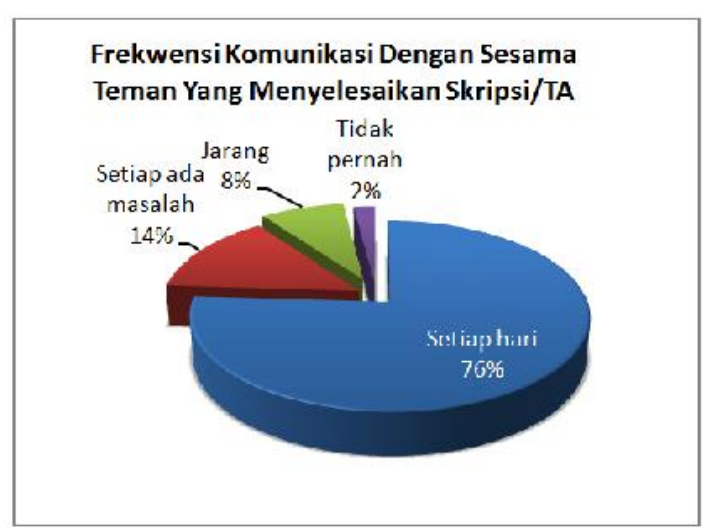

Gambar 11. Sebaran Frekwensi Komunikasi

Mahasiswa Yang Menyelesaikan Skripsi/Tugas Akhir Dengan Sesama Mahasiswa Yang Menyelesaikan Skripsi/Tugas Akhir

Sedangkan sebagian kecil yang lain $(10 \%)$ justru memilih untuk mengurangi kontak dengan rekannya (8\%) atau bahkan menghilang dan mengasingkan diri dengan permasalahan yang dihadapinya (2\%). Pribadi yang demikian ini biasanya 
memiliki kemungkinan antara terlalu sibuk dengan urusannya yang lain atau justru berusaha menghindarkan diri dari tekanan psikologis yang dirasakannya ketika ia menghadapi lingkungan yang memiliki permasalahan yang sama dengan dirinya.

\section{Media Yang Digunakan Untuk Berkomunikasi}

Kemajuan dunia teknologi yang terjadi akhir-akhir ini tidak dipungkiri telah menggeser pola komunikasi antar individu maupun kelompk yang terjadi. Dengan adanya teknologi yang serba canggih dan dapat diakses oleh siapapun menjadikan proses komunikasi lebih terjamin privasinya dan dapat lebih mudah dilakukan kapaunpun dan dimanapun bahkan oleh siapapun.

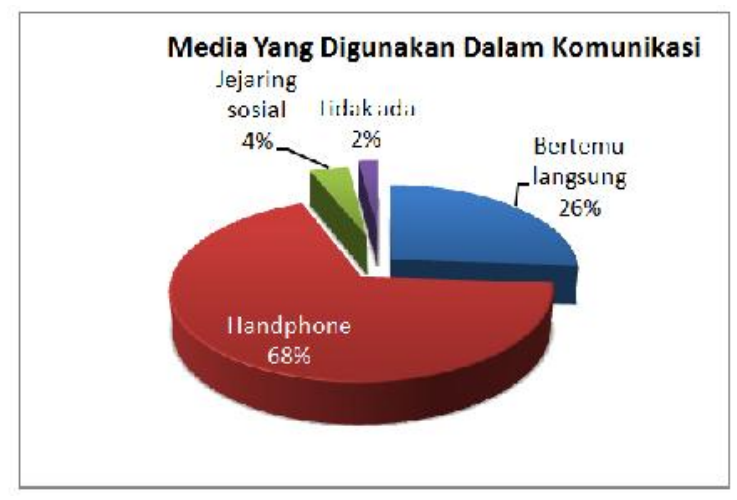

Gambar 12. Sebaran Jenis Media Yang Diunakan Untuk Berkomunikasi Mahasiswa Yang Menyelesaikan Skripsi/Tugas Akhir

Kondisi yang serupa juga terjadi dalam dunia pendidikan dimana komunikasi tidak selalu terjadi secara langsung disatu tempat yang sama, kini dimanapun lokasi memisahkan selama terdapat sinyal yang dapat menghubungkan maka akan dapat individu tersebut dijangkau. Seperti yang terpapar pada gamabar 12 diatas, dimana responden lebih banyak yang memilih telepon seluler (handphone) sebagai pilihan utama dalam berkomunikasi antara mereka (68\%), sedangkan 26 persen diantara responden lebih memilih untuk tetap melakukan pertemuan secara langsung. Sedangkan sebagian kecil sisanya lebih memilih untuk menggunakan jejaring sosial sebagai media komunikasi yang dipilih (4\%). Namun hal ini tidak berarti responden yang memilih komunikasi melalui telepon seluler tidak melakukan kounikasi dengan cara yang lainnya dan begitu juga sebaliknya. Melaikan data ini hanya menampilkan kecenderung prioritas pilihan media komunikasi yang menjadi pilihan utama responden dalam melakukan proses komunikasi dengan lingkungannya.

\section{Dampak Komunikasi Terhadap Semangat Dalam Menyelesaikan Skripsi/Tugas Akhir}

Pentingnya komunikasi bagi tiap individu tentunya akan membawa dampak yang signifikan bagi setiap individu yang terlibat, sebagaimana yang terlihat dalam gambar 13 diatas, dimana lebih dari 86 persen responden akan merasakan adanya peningkatan semangat dalam dirinya dalam menghadapi skripsi/tugas akhir yang sedang dihadapi. Tentunya dampak ini akan dapat diperoleh ketika proses komunikasi yang diterapkan merupakan komunikasi yang bersifat positif dan bertujuan untuk menemukan resolusi atas permasalahan yang dihadapi. Meski terlihat jika sebagian kecil merasa tidak mendapat pengaruh apapun dari proses komunikasi yang dilakukan $(8 \%)$ dan sebagian kecil yang lain merasa biasabiasa saja $(6 \%)$, namun besarnya jumlah responden yang menyatakan adanya pengaruh signifikasi akan proses komunikasi yang telah dilakukan menampilkan bukti konkret akan adanya manfaat komunikasi ketika komunikasi 
dilakukan dengan tujuan dan harapan yang terdefinisikan dengan jelas.

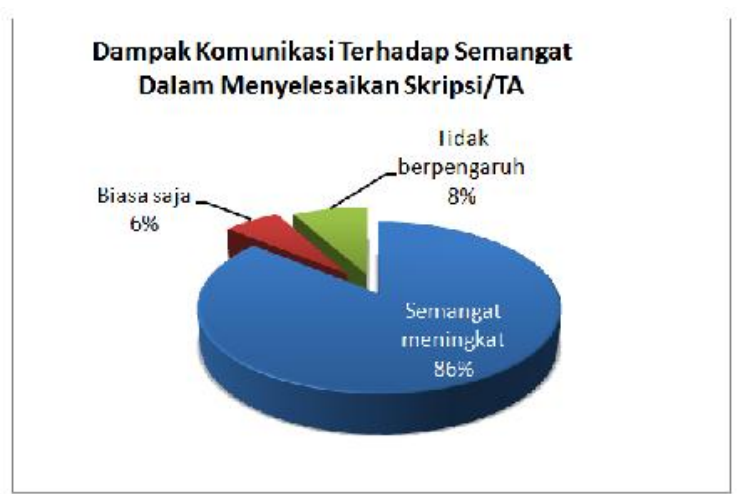

Gambar 13. Sebaran Dampak Komunikasi Terhadap Semangat Mahasiswa Dalam Menyelesaikan Skripsi/Tugas Akhir

\section{Bentuk Dukungan Yang Dapat} Memberikan Ketenangan Ketika Menyelesaikan Skripsi/Tugas Akhir Bagi Mahasiswa

Dalam prespektif mahasiswa yang sedang mengerjakan skripsi/tugas akhir memang terkadang dorongan yang diberikan lingkungan justru akan dianggap sebagi tambanhan tekanan yang harus ditanggungnya sebagai mahasiswa yang sedang mengerjakan skripsi, namun bagaimanapun juga mahasiswa yang sedang mengerjakan skripsi/tugas akhir tetaplah akan membutuhkan adanya dukungan dari lingkungannya meski dukungan yang diharapkan relatif beragam.

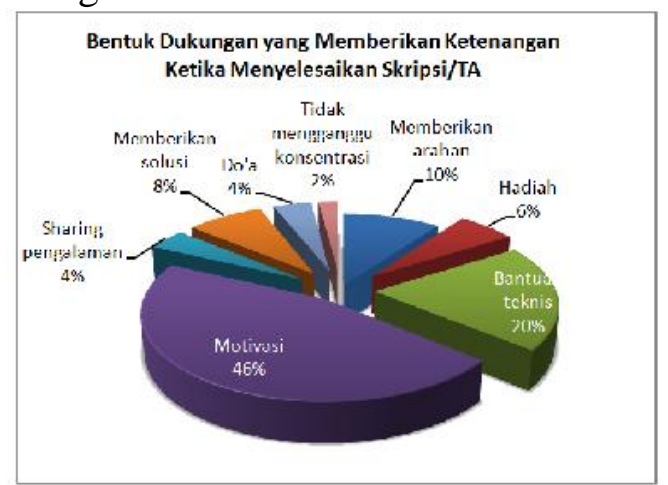

Gambar 14. Sebaran Bentuk Dukungan Yang Dapat Memberikan Ketenangan Mahasiswa Ketika Menyelesaikan Skripsi/Tugas Akhir
Keberagaman dukungan yang dipersepsikan akan dapat memberikan ketenangan bagi responden ketika ia menyelesaikan skripsi/tugas akhir sebagaimana yang terlihat pada gambar 14 tampak jika pemberian motivasi dari lingkungan merupakan dukungan terbesar (46\%) yang dipersepsikan dapat memberikan ketenangan. Motivasi ini dapat berbentuk perhatian, pertanyaan tentang progress/kemajuan dari proses skripsi yang dilakukan hingga menanyakan kebutuhan yang dibutuhkan responden.

Setelah itu tawaran bantuan teknis menjadi dukungan terbesar kedua (20\%) yang menenangkan, dukungan ini dapat berupa peminjaman literatur, bantuan pengambilan data, pengolahan data hingga bantuan berupa peminjaman instrumen yang dibutuhkan untuk penelitian. Pemberian saran dan arahan juga turut dipersepsikan sebagai bentuk dukungan yang dapat memberikan ketenangan bagi responden sebesar 10 persen. Disusul dengan pemberian solusi $(8 \%)$ dan pemberian janji akan diberikan hadiah ketika berhasil menyelesaikan skripsi/tugas akhir juga turut menyebabkan ketenangan bagi responden sebesar 6 persen.

Selain itu dukungan dengan sharing pengalaman dan pemberian restu berupa doa juga turut dipersepsikan menjadi dukungan yang dapat menyebabkan ketenangan sebesar masing-masing 4 persen bagi responden. Bahkan hanya dengan menjaga perilaku yang tidak menggangu konsentrasi responden terhadap proses pengerjaan skripsi/tugas akhir turut dipersepsikan sebagai bentuk dukungan yang akan memberikan ketenangan oleh 2 persen responden. 
Pola Komunikasi Yang Dibutuhkan Dalam Menghadapi Masalah Ketika Menyelesaikan Skripsi/Tugas Akhir

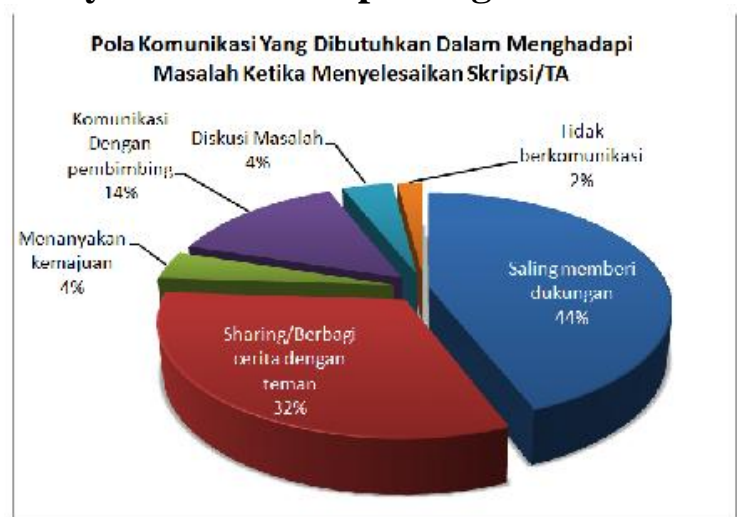

Gambar 15. Sebaran Pola Komunikasi Yang Dibutuhkan Mahasiswa Dalam Menghadapi Masalah Ketika Menyelesaikan Skripsi/Tugas Akhir

Pada gambar 15 diatas terlihat jika pada saat menghadapi tekanan dalam menyelesaikan skripsi/tugas akhir, responden akan sangat membutuhkan adanya dukungan dari teman seperjuangan (peer group) karena dukungan dari teman seperjuangan akan dianggap sebagai dukungan yang paling sesuai karena merasakan perasaan yang sama sebagaimana dinamika perasaan yang dirasakan oleh mahasiswa yang lainnya ketika menyelesaikan skripsi/tugas akhir, oleh karena itulah bentuk dukungan seperti ini menurut 44 persen responden akan menjadi pola komunikasi yang paling tepat. Selain itu pola komunikasi dengan berbagi pengalaman juga turut dianggap sebagai salah satu pola komunikasi yang paling tepat oleh 32 persen responden yang lain, karena dengan cara inilah mereka akan dapat menemukan posisinya diantara kelompoknya.

Sementara itu komunikasi dengan pembimbing menjadi pola komunikasi yang lain yang turut dipersepsikan oleh 14 persen responden sebagai pola komunikasi yang dapat membantu responden dalam menghadapi masalahnya. Sedangkan sebesar 10 persen responden menyatakan jika mereka akan lebih memilih untuk menanyakan kemajuan antara satu engan yang lain (4\%) atau mendiskusikan masalah yang dihadapi secara bersamasama (4\%) dan 2 persen yang lain lebih memilih untuk membatasi diri dan menghindarkan dari proses komunikasi dengan lingkungannya.

\section{KESIMPULAN DAN SARAN}

\section{Kesimpulan}

Dari paparan di atas dapat disimpulkan jika dalam menghadapi tekanan ketika menyelesaikan skripsi/tugas akhir mahasiswa akan menghadapi beberapa permasalahan diantaranya kesulitan memperoleh referensi, mengalami perasaan takut tidak dapat lulus tepat waktu, banyak mengalami revisi, kurang memahami teori, kesulitan dalam menemui dosen pembimbing, kurangnya rasa percaya diri, serta kesulitan dalam membagi waktu.

Untuk menghadapi tekanan psikologis dari permasalahanpermasalahan tersebut mereka membutuhkan adanya dukungan dari lingkungan dalam bentuk pemberian motivasi, dukungan bantuan teknis, diberikannya arahan dari orang yang lebih memahami tentang permasalahan yang dihadapi, dukungan solusi yang tepat, adanya sharing pengalaman dari lingkungan, dukungan dalam bentuk doa/support spiritual, serta perilaku lingkungan yang tidak menggangu konsentrasi dalam penyelesaian skripsi/tugas akhir.

Selain itu untuk menghadapi tekanan yang dirasakan ketika menyelesaikan skripsi, mahasiswa mengembangkan pola komunikasi sosial dalam menyampaikan masalah yang dihadapi dengan 
menceritakan secara langsung
permasalahan yang dihadapi pada lingkungan di sekitarnya, membuka forum diskusi untuk meningkatkan pemahamannya akan konsep yang akan diteliti, membuka diri terhadap saran dan masukan dari pihak lain, meminta bantuan teknis dari lingkungannya, menyimpan masalah yang dihadapi dari orang lain, hingga meratapi permasalahannya sendiri dan menutup diri dari lingkungannya.

Sedangkan pola komunikasi konstruktif yang paling tepat yang dapat dikembangkan oleh mahasiswa agar dapat membantu dalam mempertahankan semangat ketika menghadapi tekanan psikologis saat menghadapi tugas akhir yaitu dengan saling memberi dukungan antar kelompoknya yang memiliki permasalahan yang serupa, saling berbagi pengalaman, tetap menjaga komunikasi dengan dosen pembimbing, mendiskusikan permasalahan yang dihadapi dengan orang lain dengan tujuan untuk mendapatkan pencerahan/insight, saling menanyakan kemajuan antara mahasiswa satu dengan yang lain dengan tanpa merasa saling menyudutkan, hingga menarik diri dari lingkungan dan mengurangi pertukaran informasi dengan orang lain dengan tujuan untuk menjaga konsentrasinya terhadap penyelesaian skripsi/tugas akhir.

\section{Saran}

Berdasarkan simpulan penelitian yang didapatkan maka dapat diajukan saransaran sebagai berikut :

1. Bagi Mahasiswa Penempuh Program Tugas Akhir/Skripsi

Dalam menjalani penyelesaian tugas akhir/skripsi, mahasiswa dapat membentuk kelompok (peer group) yang saling memberikan kontribusi positif dengan jalan meningkatkan komunikasi konstruktif, membentuk forum-forum diskusi yang menunjang penyelesaian tugas akhir, serta memberikan pola komunikasi yang terbuka sehingga terbentuk ikatan emosional yang dapat meningkatkan motivasi dalam menyelesaikan tugas akhir. Selain itu, perlu meningkatkan intensitas dan frekwensi pertemuan dengan dosen pembimbing untuk menjaga motivasi sekaligus mencari solusi tentang problem yang dihadapi dalam penyelesaian tugas akhir.

2. Bagi Dosen Pembimbing Skripsi

Perlu mengembangkan pola komunikasi konstruktif dengan lebih memberikan keterbukaan, mengembangkan sikap penerimaan terhadap usaha yang dilakukan mahasiswa sebagai bentuk proses pembelajaran (bukan sekedar melihat hasil melainkan perlu penekanan pada proses), serta selalu memberikan motivasi kepada mahasiswa yang dapat dilakukan dalam bentuk menanyakan perkembangan proses penyelesaian skripsi meski di luar waktuwaktu bimbingan yang sudah dijadwalkan. Selain itu, dosen pembimbing skripsi dapat berperan sebagai mediator dalam diskusi dari beberapa mahasiswa (dapat dipertemukan dalam sesi bimbingan) yang dibimbing.

\section{Bagi Pengelola Perguruan Tinggi}

Mengingat mahasiswa yang sedang menempuh program tugas akhir/skripsi adalah mahasiswa yang sudah tidak menempuh mata kuliah yang diselenggarakan di ruang kelas, maka pengelola perguruan tinggi khususnya program studi perlu membangun sistem yang memungkinkan bagi mahasiswa yang sedang menempuh tugas akhir/skripsi dapat saling bertemu dan saling bertukar informasi, diskusi, dan saling memberikan motivasi. Hal ini dapat 
dilakukan dengan pembentukan kelompok-kelompok bagi mahasiswa yang sedang menempuh tugas akhir/skripsi.

\section{DAFTAR PUSTAKA}

Barrody, A.J. 1993. Problem Solving, Reasoning and Communicating, $K$ 8: Helping Children Think Mathematically. Macmilan. New York-USA

Brannen, J. 1997. Memadu metode penelitian : kualitatif dan kuantitatif. Pustaka Pelajar. Yogyakarta

Fine, D. 2008. Seni Memenangkan Hati Klien: Membawakan Presentasi Memukau dan Menyelesaikan Konflik di Tempat Kerja. Gramedia Pustaka Utama. Jakarta

Hawari, D. 2001. Manajemen stress, cemas dan depresi. Balai Penerbit FKUI. Jakarta

Lazarus, R.S. dan S. Folkman. 1984. Stress, Appraisal, and Coping. Springer Publishing Company. New York-USA
Maifrisco, O. Pengaruh Aromaterapi Terhadap Tingkat Stres Mahasiswa. http://www.scribd.com/doc/2235549 1/Pengaruh-Aromaterapi-TerhadapTingkat-Stres-Mahasiswa. Diakses tanggal 10 Januari 2013

Miles, M.B. dan M.A. Huberman. 1992. Analisis Data Kualitatif. UI Press. Jakarta

Poerwodarminto. 1986. Kamus Umum Bahasa Indonesia.Balai Pustaka. Jakarta

Rakhmat, J. 2004. Psikologi Komunikasi. Remaja Rosdakarya. Bandung

Santrock. 2003. Life Span Development Jilid 2. Erlangga. Jakarta

Sarwono, S.W. 2002. Psikologi Sosial: Individu dan Teori-Teori Psikologi Sosial. Balai Pustaka. Jakarta

Tatan. 2012. Analisis Prokrastinasi Tugas Akhir/Skripsi, Proceeding Seminar Nasional Matematika Dan Pendidikan Matematika. FMIPAUNY. Jogjakarta

Vaux, A. 1988. Social support: Theory, research, and intervention. Praeger. New York-USA 